\title{
The Epidemiology, Transmissions and Risk Factors of SARS-CoV-2
}

\author{
Roberto Badaró $^{1 *}$, Bruna Aparecida Souza Machado ${ }^{1}$, Milena Soares ${ }^{1}$, Luciana Knop ${ }^{1}$ \\ ${ }^{I}$ SENAI Institute of Innovation (ISI) in Advanced Health Systems; Salvador, Bahia, Brazil
}

\begin{abstract}
The outbreak of a novel coronavirus (SARS-CoV-2) and associated COVID-19 disease in late December 2019 has led to a global pandemic, spreading very quickly and causing a more than 500,000 deaths in less than six monhs of the ourbreak. The incidence differs by country and depends on many agents, such as population density, demography, the amount of testing people and reporting, and actions of mitigation strategies, provisions of sanitary and education of the society. In this article, we presented the current studies about the epidemiology of COVID-19, including the transmission routes of the SARSCoV-2, the incubation period, the reproduction number (R0), the case fatality risks (CFR), comorbidities and measures prevention against COVID-19. We searched the articles in the main database (PubMed/ Medline, Elsevier Science Direct, Scopus, Isi Web of Science, Embase, Exerpta Medica, UptoDate, Lilacs, Novel Coronavirus Resource Directory from Elsevier), in the high-impact international scientific Journals (Scimago Journal and Country Rank - SJR - and Journal Citation Reports - JCR), such as The Lancet, Science, Nature, The New England Journal of Medicine, Physiological Reviews, Journal of the American Medical Association, Plos One, Journal of Clinical Investigation, and in the data from Center for Disease Control (CDC), National Institutes of Health (NIH), National Institute of Allergy and Infectious Diseases (NIAID) and World Health Organization (WHO). We prior selected meta-analysis, systematic reviews, article reviews and original articles in this order. We reviewed 235 articles and used 131 from March to June 2020, using the terms coronavirus, SARS-CoV-2, novel coronavirus, Wuhan coronavirus, severe acute respiratory syndrome, 2019-nCoV, 2019 novel coronavirus, n-CoV-2, covid, n-Sars-2, COVID-19, corona virus, coronaviruses, epidemiology of COVID-19, risk factors, viral spreading, transmissions, routes, animals incubation, period, R0, CFR, comorbidities, prevention, with the tools MeSH (Medical Subject Headings), AND, OR, and characters $[, “, ;$, ., to ensure the best review topics. We concluded that the epidemiological data is very important to predict the transmission risks rate, purpose public political policies of mitigating the disease, and protect the vulnerable population. Also, it is important reconsider the legislation about wild animals, the potential intermediate host(s) of various viruses, as well as the conditions of live for animals for human comsuption to prevent future outbreaks.
\end{abstract}

Keywords: COVID-19. SARS-CoV-2. Epidemiology. Transmission. Risk Factors.

\section{Introduction}

Epidemiological and a Brief Overview of COVID-19 Outbreak

An outbreak of pneumonia of unknown origin was reported in Wuhan, Hubei (China) in December 2019 [1-3]. When the virus started to spread, the patients were being diagnosed with severe acute respiratory infection symptoms,

Received on 2 March 2020; revised 9 June 2020.

Address for correspondence: ISI-SENAI CIMATEC. Av. Orlando Gomes, 1845, Piatã. Zip Code: 41650-010. Salvador, Bahia, Brazil. E-mail: jbth@jbth.com.br.

J Bioeng. Tech. Appl. Health

(D) 2020 by SENAI CIMATEC. or acute respiratory distress syndrome, acute respiratory failure, and some with serious complications leading to death $[1,4]$. On January 7, 2020, the Chinese Center for Disease Control and Prevention (CCDC) identified the novel coronavirus, and on February 11, 2020, World Health Organization (WHO) named the epidemic disease as a 2019-new coronavirus disease (2019nCoV, now called COVID-19) [5]. The name coronaviruses are attributed to their appearance they look like a corona, or crown, because of the presence of spike glycoproteins on their envelope (Figure 1).

Coronaviruses belong to the family Coronaviridae (order Nidovirales). It is an RNAvirus and its genome has approximately 26-32 kilobases [8]. The family of coronaviruses is divided into four genera: Alpha, Beta, Gamma, and 
Delta-coronavirus. Seven human coronaviruses (HCoVs) have been recognized until now. These viruses typically affect the respiratory tracts of birds and mammals. In humans, CoVs generally cause a common cold; notwithstanding, some recent CoVs can cause more critical diseases, including severe acute respiratory syndrome (SARS-CoV) and the Middle East respiratory syndrome (MERS-CoV) [9, 10]. The Alphacoronavirus genus includes HCoVNL63 and HCoV-229E, while the Betacoronavirus genus, HCoV-OC43, HCoV-HKU1, SARSCoV-1, MERS-CoV, and the novel SARS-CoV-2 [11-16].

In general, bats and rodents are the reservoirs for alphaCoV and betaCoV, and the reservoir for deltaCoV and gammaCoV is not certain. So, the reservoir of these viruses is in wild animals that infrequent spillover into humans, so an intermediate host species has to exist to infect humans. On March 19, 2020, Pradhan and colleagues revealed that the Pangolin$\mathrm{CoV}$ genome showed $91.02 \%$ and $90.55 \%$ nucleotide correspondence with SARS-CoV-2 and BatCoV RaTG13, respectively. This study gives the first report of a potential nearly related the SARS-CoV-2 to Pangolin-CoV, recognizing the pangolin the most likely intermediate host for the new coronavirus [17] (Figure 2).

So, after infection with SARS-CoV-2, the virus binds to the human angiotensinconverting enzyme 2 receptors (ACE2) abundantly located on respiratory tract and also intestinal, uroepithelial cells, salivary gland duct epithelium in the human mouth, and other epithelial organs $[19,20]$. Figure 3 presents the life cycle and mechanism of pathogenicity of SARS-CoV-2.

This article aimed to present the current studies about the epidemiology of COVID-19, including the transmission routes of the SARS$\mathrm{CoV}-2$, the incubation period, the reproduction number (R0), the case fatality risks (CFR), comorbidities and measures prevention against COVID-19.

\section{Epidemiology of COVID-19}

\section{Geographical Distribution}

Since the beginning of the epidemic in late December 2019, SARS-CoV-2 has spread quickly to countries and territories all over the world [22]. The incidence of the disease differs by country and states and depends on many circumstances, including population density and demographics, the amount of testing and reporting, and the mitigation strategies [23-25]. Globally, more than seven million confirmed cases of COVID-19 have been reported. As of June 11, 2020, COVID-19 has affected 7,403,713 people in 188 countries and territories worldwide and left 417.174 deaths [26]. The source for the epidemiology of this emerging pandemic can be found in many websites such as John Hopkins Coronavirus Research Center [26], World Health Organization (WHO) Coronavirus Disease Dashboard [27], Worldmeters [28], Healthmap Coronavirus [29], Uptodate Worldwide Coronavirus [30], COVID-19 Health Data [31], Centers for Disease Control and Prevention (CDC) [32], Our World in Data-COVID-19 [33] (Figures 4-7), which present dashboards, metrics, infographics about the virus spreading, as well as all news about the novel SARS-CoV-2.

\section{Epidemic Curve of Infection}

The epidemic curve of COVID-19 is a statistical chart used in epidemiology to visualize the onset of the outbreak. The epidemic curve is currently being divided into three zones (Table 1) [34].

\section{$\underline{\text { Transmission of COVID-19 }}$}

In contrast to SARS-CoV-1 and MERS, the worldwide spread of SARS-CoV-2 demonstrates the differences in how the virus may be transmitted [35], and also its association with high viral loads in the upper respiratory tract [36] and significant asymptomatic carriage [37-40]. 
Figure 1. Structure of SARS-CoV-2.

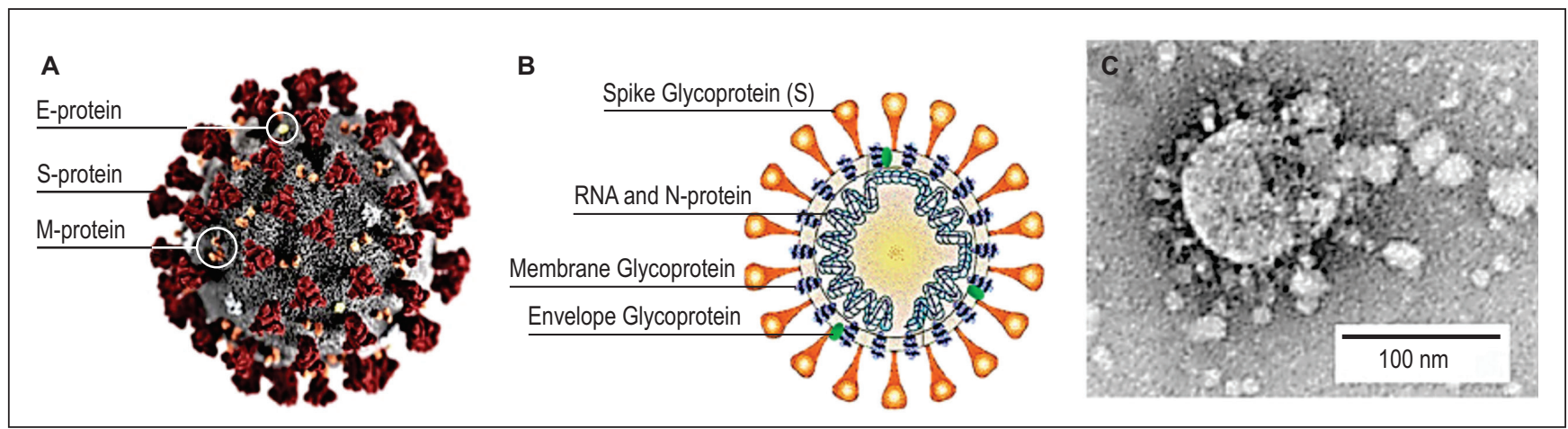

(A) Illustration of the SARS-CoV-2 virion created at the Centers for Disease Control and Prevention (CDC). The spikes on the outer edge of the virus particles look like a crown, giving the disease its characteristic name. (B) Schematic representation of the structure of SARS$\mathrm{CoV}-2$. It has four structural proteins, S (spike), E (envelope), M (membrane), and N (nucleocapsid) proteins; the N protein holds the RNA genome, and the S, E, and M proteins together create the viral envelope. (C) An electron microscopic image of a thin section of SARSCoV-2 within the cytoplasm of an infected cell, showing the spherical particles and cross-sections through the viral nucleocapsid [6]. Source/Credit: Tarek and colleagues [7].

Figure 2. Timeline of coronavirus.

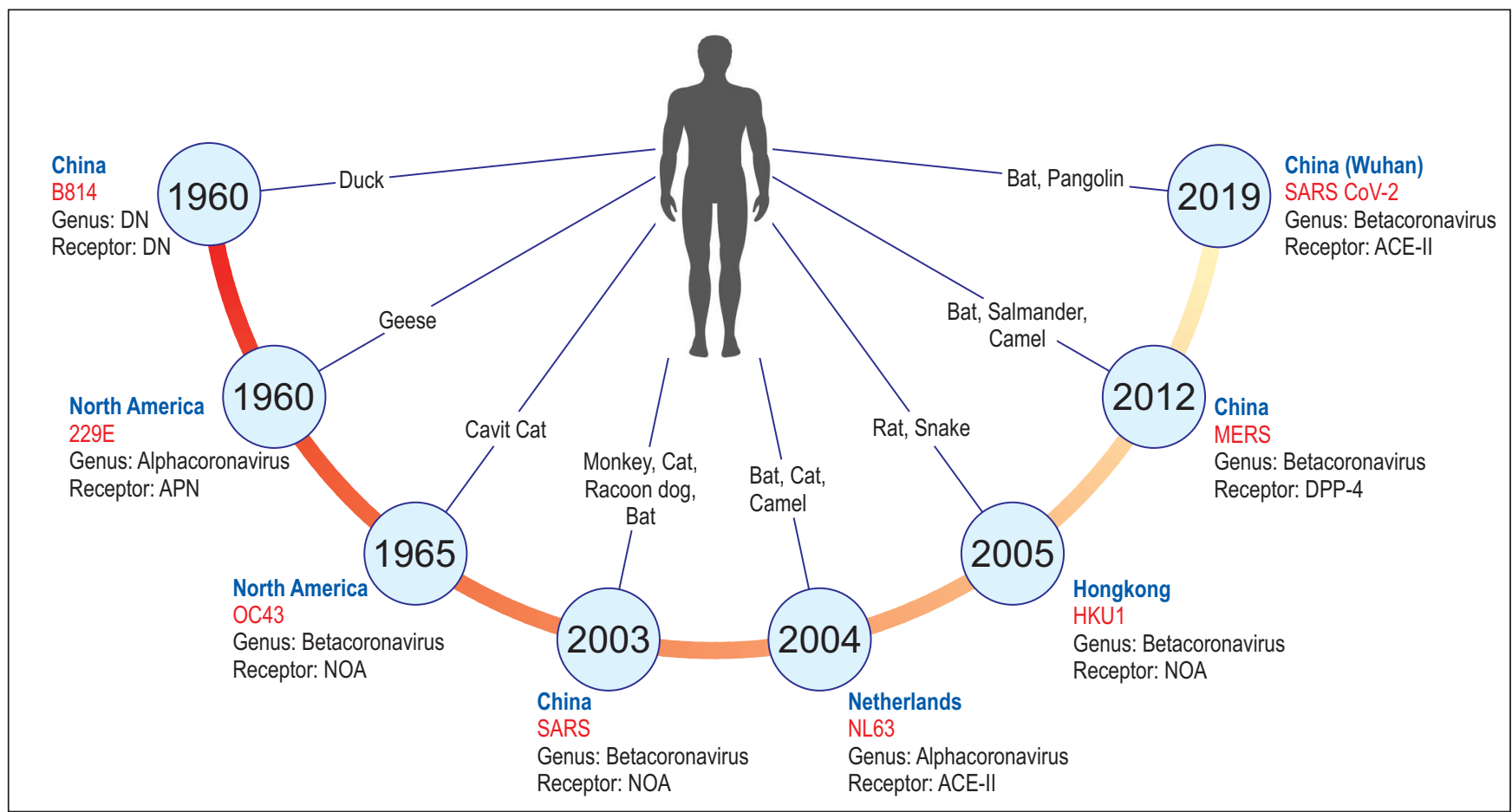

CS, Coronavirus strain; APN, amino-peptidase-N receptor; ACE-II, Angiotensin-converting enzyme II; NOA, N-acetyl-9-O-acetylneuraminic acid; DPP-4, Dipeptidyl peptidase 4; SARS, Severe acute respiratory syndrome; SARS CoV-2, Severe acute respiratory syndrome-2 also known as COVID-19/2019-nCoV; MERS, Middle East Respiratory Syndrome.

The hypothesis emerged through the ingesting of an infected animal (probably a Pangolin) by a human cause the animal-man transmission of the virus and due to close contact with an infected person, the virus is further transmitted to healthy persons. However, there are no documented cases of direct bat-human transmission [7].

Source/Credit: Adapted from Pradhan and colleagues [18]. 
Figure 3. SARS-CoV-2 life-cycle in human lung cells.

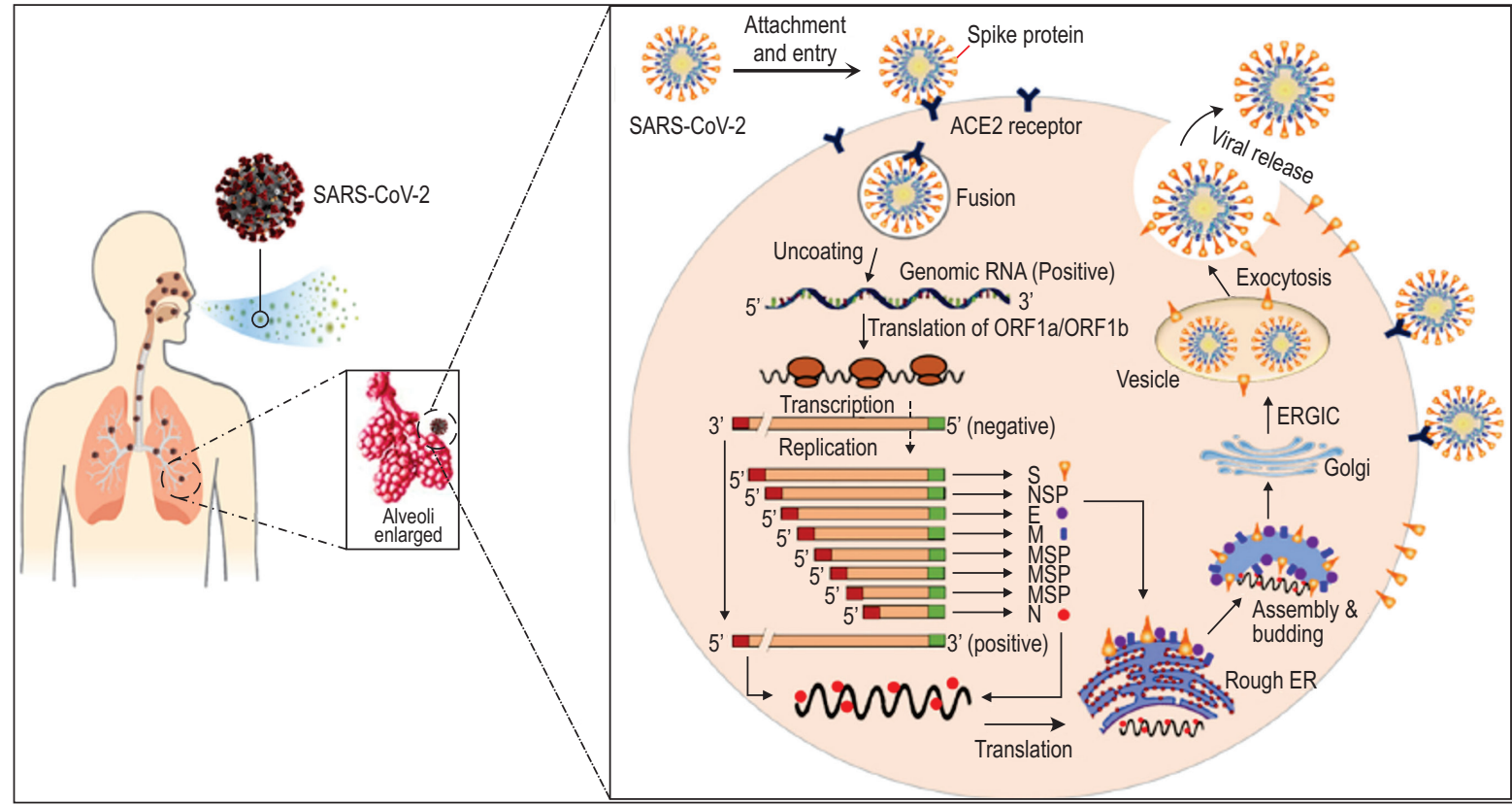

Coronavirus is most often transmitted by droplets while sneezing and coughing and its journey begins in the first days after infiltration from the upper respiratory tract. The spike proteins of SARS-CoV-2 binds to ACE2 receptors. The virion then releases the RNA genome into the cell and translation of structural and non-structural proteins follows. ORF1a and ORF1ab are translated to produce ppla and pplab polyproteins, which are cleaved by the proteases that are encoded by ORF1a to yield non-structural proteins. This is followed by assembly and budding into the lumen of the ERGIC. Virions are then released from the infected cell through exocytosis [21].

Source/Credit: Tarek and colleagues [7].

Figure 4. The dashboard of the John Hopkins Coronavirus Research Center (June 11, 2020).

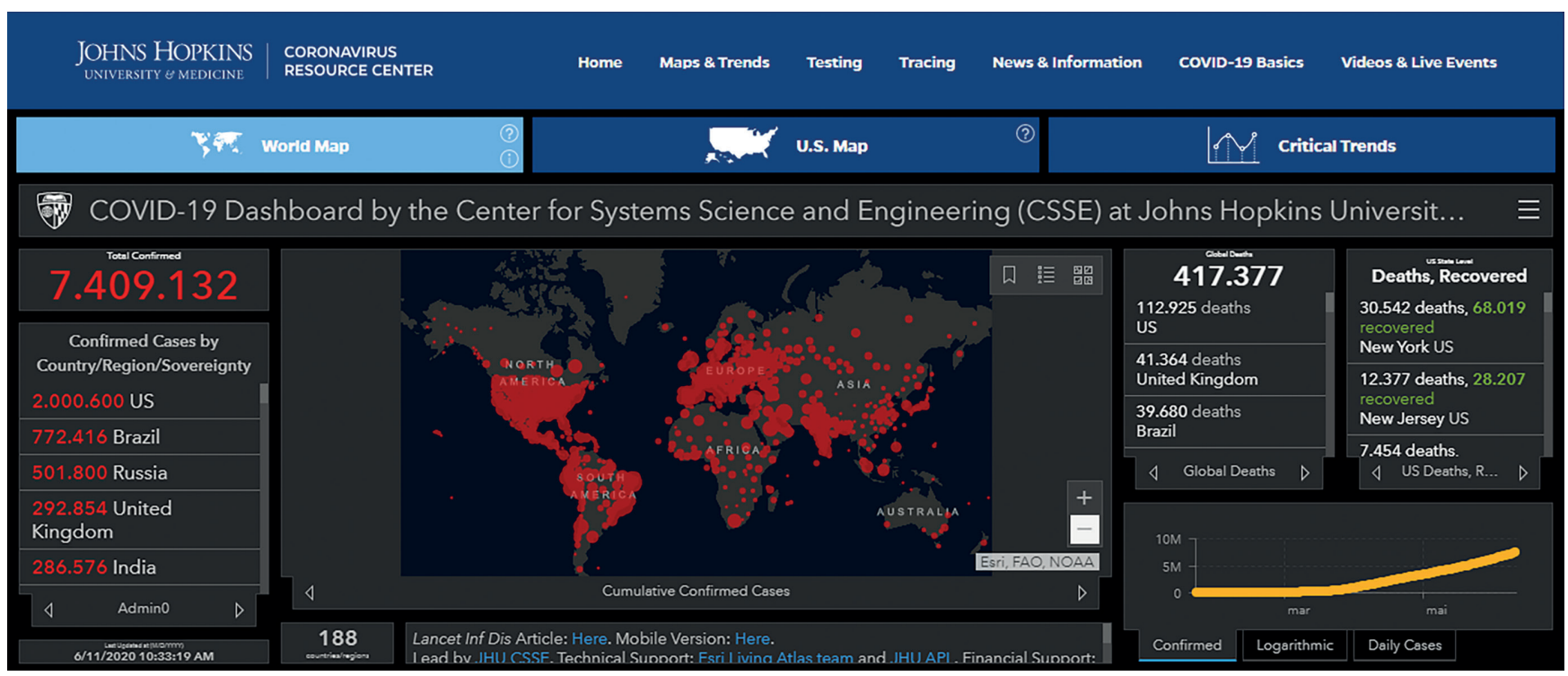

Source/Credit: The John Hopkins Coronavirus Research Center [26]. 
Figure 5. Daily confirmed COVID-19 deaths per million people.

Limited testing and challenges in the attribution of the cause of death means that the number of confirmed deaths may not be an accurate count of the true number of deaths from COVID-19.

20

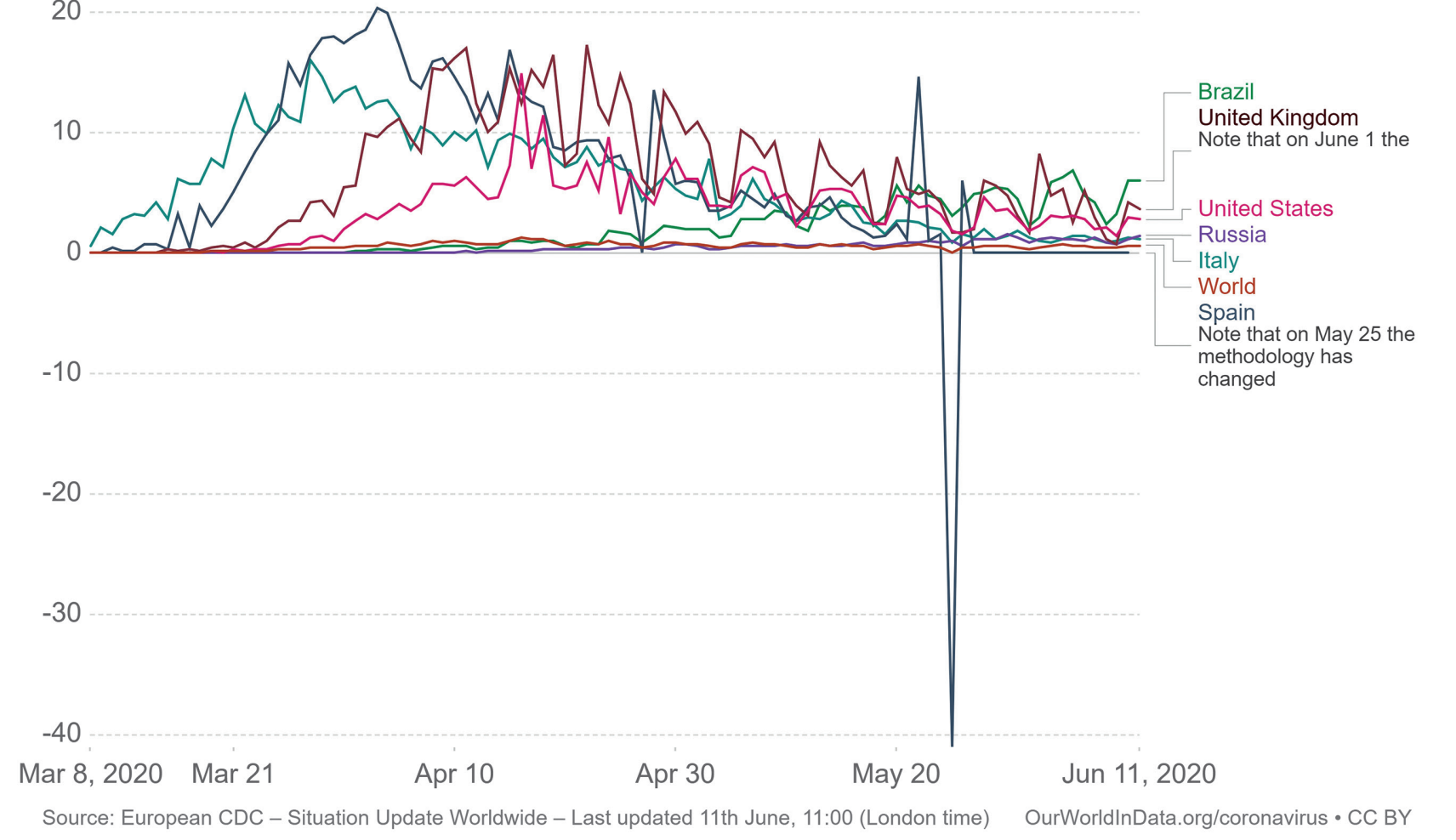

Source/Credit: European CDC - Update worldwide [33].

Figure 6. Projection of deaths to Brazil until September 1 $1^{\text {st }}, 2020$.

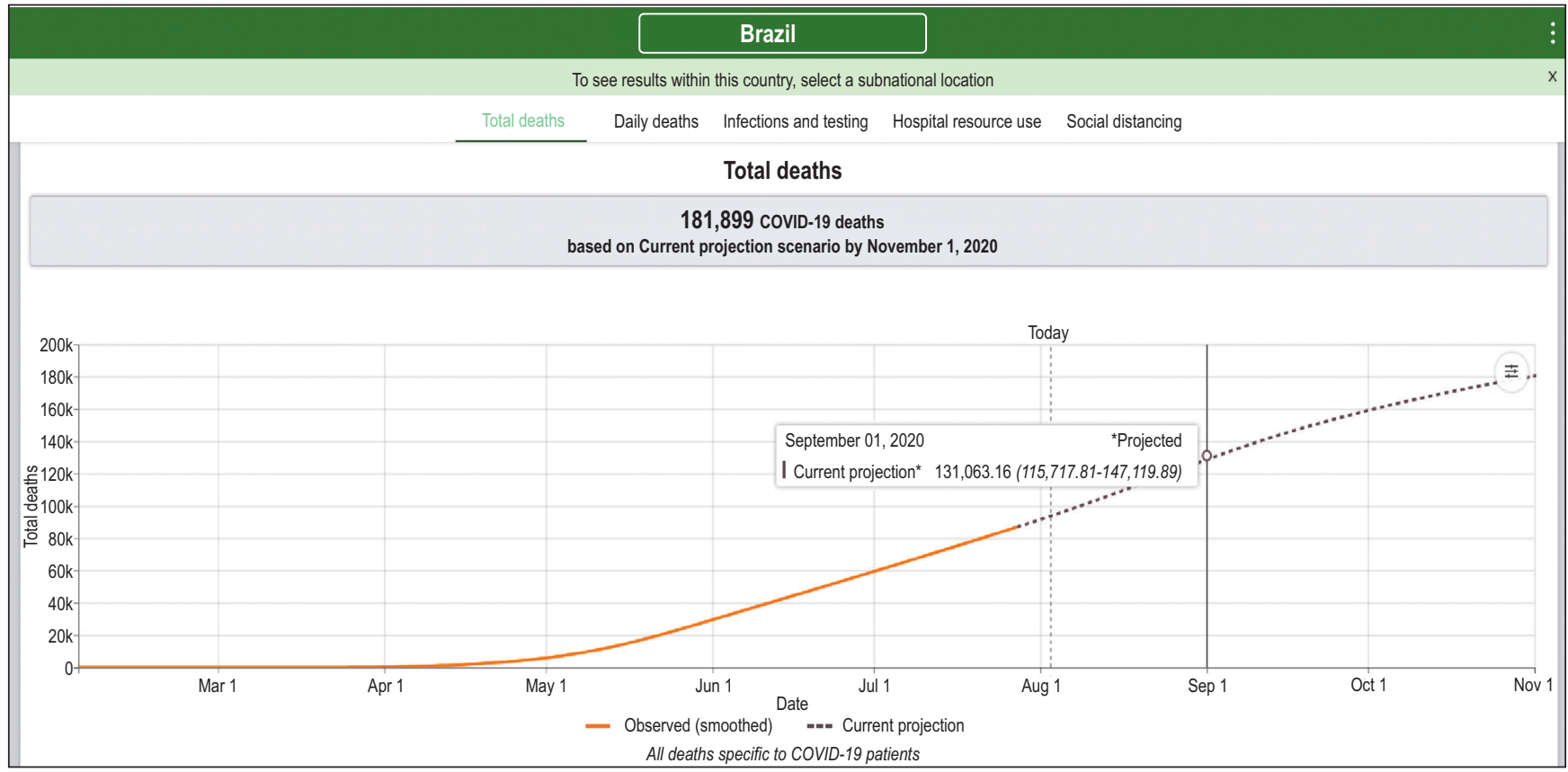

Source/Credit: COVID-19 Health Data [31]. 
Figure 7. Projection of hospital resource of Brazil until September $1^{\text {st }}, 2020$.

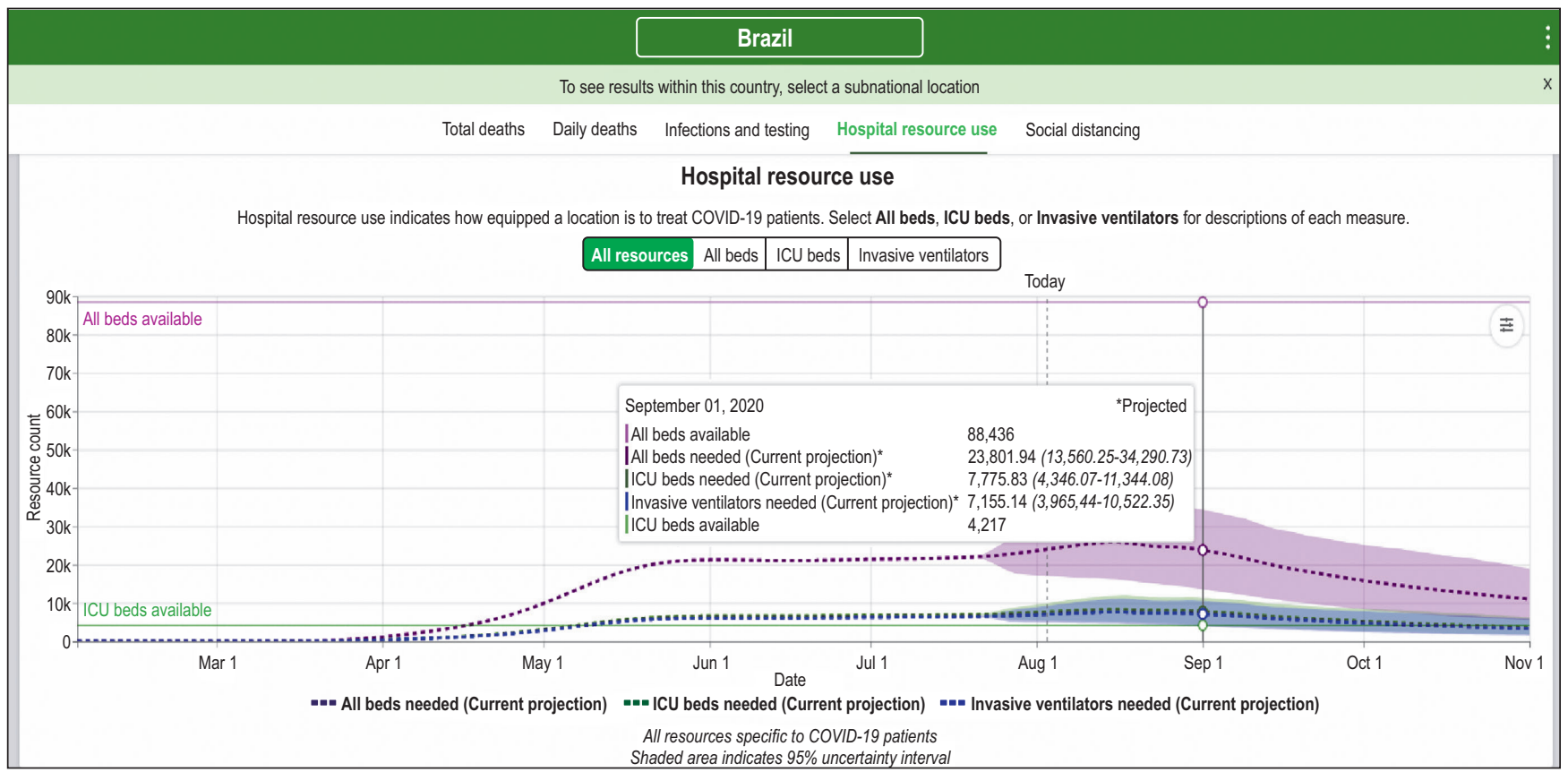

Source/Credit: COVID-19 Health Data [31].

Table 1. The three zones of an epidemic curve infection.

\begin{tabular}{ll}
\hline Zones & Descripton \\
\hline Increasing & $\begin{array}{l}\text { Country demographics, age distribution, the preparedness of health system to an outbreak, implementation } \\
\text { of some preventive measures, country reaction time to a pandemic, the reaction of society to new } \\
\text { implementing rules. This period takes generally } 3 \text { or } 4 \text { weeks for COVID-19. }\end{array}$ \\
Plateau & $\begin{array}{l}\text { The disease incidence is stable. It takes } 2 \text { or } 3 \text { weeks for COVID-19 concerning daily country reports. } \\
\text { Declining }\end{array}$ \\
& $\begin{array}{l}\text { In this phase, it is possible to see the decline of the infection data. } 2 \text { or } 3 \text { weeks later disease activity } \\
\text { could be detected very low levels for COVID-19. }\end{array}$ \\
\hline
\end{tabular}

\section{$\underline{\text { Transmission Route }}$}

As the outbreak advanced, person-to-person spread became the principal mode of transmission [41]. Thus the usual transmission routes of COVID-19 are through direct transmission person-to-person (cough, sneeze, droplet inhalation transmission, and airborne) and contact transmission if a person touches an infected surface and then touches his or her eyes, nose, or mouth, according to multiple studies [20, 4048]. The surface route depends on the quantity of the RNA virus in the fomite, and because on some surfaces the virus can live for long periods, the contamination can occur this way $[45,49,50]$. The exact routes of person-to-person's COVID-19 transmission are still unclear. However, it is well known that it happens via respiratory droplets, and droplets typically do not go more than two meters [41]. Also, the amount of viral load in the droplets is high and it could explain the number of spreading the disease so easily. Although studies have shown that respiratory infection by COVID-19 is spread mainly by droplet inhalation or contaminated surfaces, SARS-CoV-2 was also detected in non-respiratory specimens (stool, blood, saliva, ocular secretions), but the role of these specimens in the transmission is uncertain [40-48]. Huang and colleagues [51], and Belser and colleagues [52] have been suggested that the transmission could be done through saliva, feces and conjunctival samples from confirmed cases of COVID-19, indicating that the transmission of COVID-19 is not limited to the respiratory tract. 
In a systematic review, Zhang and colleagues [54] presented that viruses could be identified in oral swabs, anal swabs, and blood samples of the patients, and highlights that the anal swabs and blood could test positive when oral swab tested negative in some cases. Cheng and colleagues [55] detected the possible transmission through the ocular surface due to a contaminated health professional that was using the mask N95 but with no protection for the eye. Furthermore, Wax and colleagues [56] and Peng and colleagues [57] have detailed specific recommendations for the prevention of COVID-19 spread in Odontology. They suggested a scale of preventive strategies to mitigate the virus spread in the dental clinic setting, such as checking the patient's body temperature, the use of rubber dam isolation to block aerosol, and the usage of personal protective equipment (PPE) (masks, goggles, gloves, caps, face shields) for all healthcare providers, and reported airborne through aerosols formed during medical procedures (odontology and surgery) that could transmit the COVID-19.A Germany study also reported one case of COVID-19 infection in which the transmission of the virus may have occurred through contact with asymptomatic patients [58]. This research suggests that infected patients possibly start to drop viruses before the beginning of any symptoms [59], and those asymptomatic carriers could spread the virus without knowing [60-62]. Another study observed that an asymptomatic patient had similar viral loads to symptomatic patients in the samples of nasal and throat swabs [36].

\section{Airborne Transmission}

New studies propose that SARS-CoV-2 can be spread through particles smaller than droplets, which could persist in the air over time and distance [34, 35]. However, the significance of this finding to the epidemiology of COVID-19 and its clinical implications is not clear. Other studies have found viral RNA in ventilation systems and air samples of hospital rooms of patients with COVID-19, but the cultures for the feasibility of the virus were not made in these studies [63-65].
Nevertheless, studies using high-speed imaging to visualize respiratory exhalings have proposed that respiratory droplets may be carried in the air and have horizontal directions beyond two meters when speaking, coughing, or sneezing $[34,41,66]$. Gou and colleagues found that air samples were positive in many different sites of wards [67]. We do not know yet whether detected SARS CoV-2 in air samples are viable or not, or whether detected viral loads are high enough to cause COVID-19 [34, 64]. However, airborne precautions are recommended when aerosolgenerating procedures are executed [41].

\section{Fecal Transmission}

Fecal transmission is an unanswered question. However, recent evidence supports the possibility of a fecally mediated route of COVID-19 transmission [34, 46, 67-76]. Wu and colleagues [77] detected positive fecal samples in patients with gastrointestinal (GI) symptoms but negative respiratory tract samples for 11 days.

Amirian [67] highlights the implications for public health of preventing potential fecal transmission if oral-fecal transmission of SARSCoV-2 will be confirmed [73]:

a. Areas with inadequate sanitation could be a location for the virus spreading [72, 78, 79].

b. Strict preventive measures should be taken by healthcare workers and laboratory staff since they constitute possible targets when handling stool or fecal samples from SARS-CoV-2 infected patients [72]. Currently, the CDC recommends that virus isolation and cultures be handled in biosafety level 3 (BSL-3) settings, whereas routine diagnostic testing is performed in a BSL-2 laboratory [80].

c. Hygienic food preparation will be another key consideration due to the contact of the hand with the food [81]. Thus, public health agencies should engage in educational tactics for staff who handle food [67].

It is not clear yet if the virus detected in stool samples is sufficient to transmit the virus. 
Nevertheless, these findings highlight the urgent need for further research on potential fecal-oral transmission and the possible significance and/ or sequelae of viral presence in the GI tract [67]. Preventive strategies should be a high public health priority due to a large number of people that this route could reach [82].

\section{Maternal-Fetal Transmission}

Schwartz [83] did not find any intrauterine or transplacental transmission from 38 infected pregnant women to their fetuses. Dashraath and colleagues [84] and Chen and colleagues [85] in other studies also reported that there is no definitive evidence of vertical transmission, followed by other studies $[34,86]$. The virus did not appear in samples of amniotic fluid, as well as seems to be not transmitted through the placenta $[34,83]$.

\section{$\underline{\text { Transmission Period }}$}

People infected with SARS-CoV-2 can be contagious before onset of symptoms and sometimes there some cases that no symptoms at all are evident but the person is spreading the virus $[6,87]$. That is why asymptomatic and presymptomatic transmission is a challenge to contact tracing, and this is an important target group to be controlled. Thus, testing becomes even more crucial to stopping the virus spreading [88]. Aditionally, viral shedding might be longer than previously thought [34].

$\underline{\text { Reproduction Number (R0) and Incubation Period }}$

The basic reproduction number (R0) is an epidemiologic metric that describes the transmissibility cases that could be caused by 1 infected patient in a susceptible population. So, for $\mathrm{R} 0>1$, the number of infected is likely to increase; for $\mathrm{R} 0<1$, the transmission is likely to decline and die out. The reproductive number updated along with the development of the outbreak and interventions [89, 90].
This number is largely used in infectious diseases. For COVID-19, it was estimated based on the study of $\mathrm{Li}$ and colleagues [22] to be 2.2 (meaning that one patient has been spreading the infection to 2.2 other people). As there were many studies with different R0 and incubation periods, we described all the numbers that the main authors have reported (Table 2 ).

However, in some important studies, another metric was used, such as the incubation period, which is the interval from initial exposure to an infectious agent to the onset of any symptoms or signs it causes. For COVID-19, Li and colleagues [22] predicted 5.2 days (mean), and Sanche and colleagues [93, 94] found that a serial interval was different when public health measures are implemented or not.

Several research groups reported an estimated R0 of the outbreak depending on distinct estimation methods and the validity of underlying assumptions. Also, the discrepancy may be due to the sample number and different stages of the pandemic. Thus, based on the authors of Table 1, we can conclude that even in the same geographic region, different $\mathrm{R} 0$ values can be calculated by using different methods, and the R0 is much larger before the control measures than after, implying that SARS-CoV-2 is highly contagious and more infectious than initially estimated. This conclusion is consistent with the widespread of SARS-CoV-2 within a short period time and was also echoed by the finding that SARS-CoV-2 spike (S) protein had 10 - to 20 -fold higher affinity to human angiotensinconverting enzyme 2 (ACE2) receptor than that of SARS-CoV-1 based on the Cryo-EM structure analysis of S proteins [103].

Yuan and colleagues [104] prefer to use other metrics, the real-time reproduction number ( $\mathrm{Rt}$ ) instead of basic reproduction number (R0), to show the Rt values for Italy, Germany, France, and Spain as 3.1, 4.43, 6.56, and 3.95, respectively.

All of this literature lays the foundation to set 14 days as the medical observation period if any exposure occurred. This number was based on of the presented studies and the definition of the 
Table 2. The R0 of COVID-19 and the incubation period.

\begin{tabular}{|c|c|c|c|}
\hline Author & R0 & Incubation Period (days) & Other observations \\
\hline $\mathrm{Wu}$ and colleagues [91] & 2.68 & Not defined & January 2020 \\
\hline $\mathrm{Li}$ and colleagues [22] & 2.2 & $\begin{array}{l}5.295 \% \mathrm{CI}, 4.1-7.0 \text { days), } \\
\text { with the } 95^{\text {th }} \text { percentile of } \\
\text { the distribution at } 12.5 \text { days }\end{array}$ & $\begin{array}{l}\text { January } 2020 \\
97.5 \% \text { of the infected subjects } \\
\text { will develop symptoms within } \\
12.5 \text { days }\end{array}$ \\
\hline Zhao and colleagues [92] & $\begin{array}{l}2.24[95 \% \text { confidence } \\
\text { interval }(\mathrm{CI}) 1.96- \\
2.55] \text { to } 3.58(95 \% \mathrm{CI} \\
2.89-4.39)\end{array}$ & Not defined & January 2020 \\
\hline Sanche and colleagues [93] & $1.4-3.0$ & 5.7 (95\% CI, 3.8-8.9 days) & After public health measures \\
\hline Sanche and colleagues [94] & $4.7-6.6$ & & Before public health measures \\
\hline Liu and colleagues [95] & $3.8(1.4-6.49)$ & Not defined & $\begin{array}{l}\text { January } 2020 \text { - a review of } 14 \\
\text { studies }\end{array}$ \\
\hline Bauch and colleagues [96] & 3.0 & Not defined & $\begin{array}{l}\text { January } 2020 \text { (Before } \\
\text { public health measures were } \\
\text { implemented) }\end{array}$ \\
\hline Yang and colleagues [97] & 3.77 & $\begin{array}{l}4.75 \text { days (interquartile } \\
\text { range: } 3.0-7.2 \text { days) }\end{array}$ & $\begin{array}{l}\text { January } 2020 \text { (4,021-case } \\
\text { study) }\end{array}$ \\
\hline Backer and colleagues [98] & Not defined & $\begin{array}{l}6.46(95 \% \text { CI, } 5.6-7.7 \\
\text { days) }\end{array}$ & $\begin{array}{l}\text { Travels histories to and from } \\
\text { Wuhan and symptom onset } \\
\text { dates }\end{array}$ \\
\hline Lesser and colleagues [99] & Not defined & 4.0 (95\% CI 3.6-4.4 days) & Systematic review \\
\hline Park and colleagues [100] & Not defined & Range 4.5-5.2 & - \\
\hline Lipsitch and colleagues [101] & Not defined & 7.5 (95\% CI, 5.3-19 days) & - \\
\hline Guan and colleagues [75] & Not defined & Up to 24 & - \\
\hline Lauer and colleagues [102] & Not defined & $1-9$ & - \\
\hline
\end{tabular}

incubation period (IP), which means the interval between the potential earliest date of contact of the transmission source (wildlife or person with suspected or confirmed case) and the potential earliest date of symptom onset (i.e. cough, fever, fatigue or myalgia) [105]. So, accorging to current studies, the incubation period for COVID-19 is 14 days following exposure, and 5.1 days is the median incubation period [75, 102, 104, 105].

\section{Viral Shedding}

The interval during which an individual with COVID-19 is infectious is not precisely determined [41]. The detection of viral RNA does not necessarily indicate the presence of the infectious virus. For example, it seems that viral RNA levels of COVID-19 from upper respiratory samples appear to be higher soon after symptom onset compared with later in the illness [36, 76, 106, 107]. Also, Wölfel and colleagues [76] presented nine patients with mild COVID-19 in which infectious virus was isolated from naso/ oropharyngeal and sputum specimens during the first eight days of illness, but not after this interval, despite continued high viral RNA levels at these sites.

A chinese study presented a model based on the timing of infection among 77 transmission pairs in which the authors suggested that the infectiousness started 2.3 days before symptom onset, peaked 0.7 days before the symptom onset, and declined within seven days [73]. These findings raise the possibility that patients might be more infectious in the earlier stage of infection [41]. Nevertheless, the transmission of SARS-CoV-2 from asymptomatic individuals (or individuals within the incubation period) has been documented [60, 87, 108-110]. Arons and colleagues [111] used reverse transcription-polymerase chain reaction (RT-PCR)-positive for samples from the 
respiratory tract in presymptomatic and asymptomatic patients as early as six days before the development of typical symptoms. However, the extent to which asymptomatic or presymptomatic transmission occurs and how much it contributes to the pandemic remains unknown.

It is not clear how long a person remains infectious due to the duration of viral RNA shedding is variable. Some studies suggest the presence of the virus depends on the severity of illness [40, 76, 112, 113]. More studies are still necessary to support this theory. Liu and colleagues [112] reported repeated negative PCR tests on nasopharyngeal swabs by 10 days after the onset of symptoms, and tests were positive for longer in patients with more severe illness. In contrast, Xiao and colleagues [114] reported 56 patients with mild to moderate illness that the median duration of viral RNA shedding from nasoor oropharyngeal specimens were 24 days, and the longest was 42 days. Yet, according to the Centers for Disease Control and Prevention (CDC), three days after recovery, if patients present detectable viral RNA in upper respiratory samples, the RNA concentrations are generally low and difficult to transmit [115]. Nevertheless, Zhou and colleagues [113], in a retrospective multicenter cohort study presented 20 days for the median duration of viral shedding (IQR 17.0-24.0) and 37 days for the longest duration of viral shedding in survivors.

Concerning how long the virus stays in surfaces, it depends on the nature of the surface, $\mathrm{pH}$, temperature, and relative humidity. The virus persistence time varies from 1 to 9 days, but it could be higher. [116] (Figure 8). However, if the surface is adequately clean, the virus is inactivated. The United States Environmental Protection Agency (USEPA) recommended some disinfectants against COVID-19 (Table 3).

Case Fatality Risk (CFR), Comorbidities and $\underline{\text { Risks for Disease and Death }}$

The case fatality risk (CFR) for COVID-19 is estimated to be $0.25 \%$ to $4.7 \%[117,118]$. It is dependent on the presence of comorbidities, age, gender, and geographic location [51]. The CFR depends on prognosis factors such as male, elderly patients aged $>60$ years, comorbidities (cardiovascular diseases, hypertension, diabetes, pulmonary disease), severe pneumonia at baseline and a delay from onset to diagnosis ( $>5$ days substantially elevated the CFRs) [75, 101, 119121]. So, CFRs in patients with cardiovascular disease, diabetes, hypertension and respiratory disorders were as high as $10.5 \%, 7.3 \%, 6.0 \%$ and $6.3 \%$, respectively [122].

In a meta-analysis, Yang and colleagues [123] evaluated 46,248 patients from eight studies, and described the most prevalent comorbidities in COVID-19 as hypertension, diabetes mellitus, cardiovascular diseases, and respiratory diseases, andalsoreported that these comorbidities weremore likely present in severe patients. In another metaanalysis, Emani and colleagues [124] listed that hypertension, cardiovascular diseases, diabetes, smoking, chronic obstructive pulmonary disease, malignancy, and chronic kidney disease were most often detected comorbidities among hospitalized patients. Also, an Italian report showed that the most frequent comorbidities related to COVID-19 cases were hypertension, diabetes, ischemic heart disease, and chronic renal failure $(72 \%, 31.5 \%$, $27.4 \%$, and $23.5 \%$, respectively), and the patients with no comorbidities the CFR rate was of $2.8 \%$ [125]. In a pooled analysis, the risk of severe disease and mortality was higher in hypertensive patients nearly 2.5 fold, and it increases especially among advanced aged individuals [126].

Regarding gender, males are often more affected than females. However, men have more comorbidities and bad habits than women, like smoking and drinking [127].

\section{Uncertain Risk of Animal Contact}

Despite there not being certainty about the transmission of SARS-CoV-2 by animals, including pets, to people, some studies have already found the virus in dogs and cats. There 
Table 3. Different surfaces and how long the virus survives.

\begin{tabular}{|lc|}
\hline Surface & Lifespan of COVID-19 virus \\
\hline Food\# & $\begin{array}{c}\text { It does not seem to } \\
\text { spread through food }\end{array}$ \\
Paper and tissue paper** & 3 hours \\
Cooper* & 4 hours \\
Aluminum\# & $2-8$ hours \\
Cardboard* & 24 hours \\
Wood** & 2 days \\
Cloth** & 2 days \\
Stainles steel* & $2-3$ days \\
Prolypoylene plastic* & 3 days \\
Glass* & $4-5$ days \\
Metal\# & 5 days \\
Ceramics\# & 5 days \\
Paper money** & 4 days \\
Outside of surgical mask** & 7 days \\
\hline
\end{tabular}

* At 69.8 to $73.4^{\circ} \mathrm{F}\left(21\right.$ to $\left.23^{\circ} \mathrm{C}\right)$ and $40 \%$ relative humidity. $* *$ At $71^{\circ} \mathrm{F}$ and $65 \%$ relative humidy.

Source/Credit: New England Journal of Medicine*; The Lance Microbe**; CDC\#, FDA\#.

Table 4. List of disinfectants for use against SARS-CoV-2/COVID-19 and how long the virus is inactivated.

\begin{tabular}{|c|c|c|}
\hline Desinfectant agent & Composition/\% & Time of desinfection (min) \\
\hline Quaternary ammonium salt & $\begin{array}{l}\text { Alkyl (C14 60\%, C16 30\%, C12 5\%, C18 5\%) } \\
\text { dimethyl derivatives } \\
\text { benzyl ammonium chloride } 25 \% \\
\text { Alkyl (C-12 68\%, C-14 32\%) dimethyl ethylbenzyl } \\
\text { ammonium chloride } 25.0 \%\end{array}$ & 10 \\
\hline Hydrogen peroxide and & 1. Hydrogen peroxide: $0.5 \%$ & 5 \\
\hline Peroxyacetic acid & $\begin{array}{l}\text { 2. Peracetic acid: }>14-17 \text {, } \\
\text { Hydrogen peroxide: }>20-<30 \text { and } \\
\text { Acetic acid: }>15-<20 \\
\text { Peracetic acid: } 15 \% \text {; Hydrogen peroxide: } 22 \%\end{array}$ & $\begin{array}{l}1 \\
1\end{array}$ \\
\hline Hydrogen peroxide; & $3.30 \%$ & 5 \\
\hline $\begin{array}{l}\text { Ammonium carbonate and } \\
\text { Ammonium bicarbonate }\end{array}$ & $1.38 \%$ & 5 \\
\hline Octanoic acid & $5-10 \%$ & 2 \\
\hline Phenolic & $\begin{array}{l}\text { Ortho-benzyl-parachlorophenol: } 3.03 \% \text {; } \\
\text { Orthophenyl phenol: } 3.40 \%\end{array}$ & 10 \\
\hline $\begin{array}{l}\text { Quaternary ammonium } \\
\text { ethanol }\end{array}$ & $\begin{array}{l}\text { Didecyldimethyl ammonium chloride: } 0.33 \% \\
\text { Ethanol: } 72.5 \%\end{array}$ & 1 \\
\hline Sodium chlorite & $30.5 \%$ & 10 \\
\hline Sodium hypochlorite & $6.0 \%$ & 10 \\
\hline Ethanol & $\begin{array}{l}\text { Ethanol: } 15-30 \% \\
\text { Butane: } 15-32 \% \\
\text { Propane:5-10\% } \\
2,2 \text { '-(ethylene dioxy)diethanol: } 5-10 \%\end{array}$ & 0.5 \\
\hline Hypochlorous acid & $0.017 \%$ & 10 \\
\hline $\begin{array}{l}\text { Quaternary ammonium; } \\
\text { Isopropanol }\end{array}$ & $\begin{array}{l}\text { Propan-2-ol:50-100\% V/V } \\
\text { Quaternary ammonium compounds: \#2\% } \\
\text { Benzyl-C7-17-alkyldimethyl chloride: \#5\% }\end{array}$ & 0.5 \\
\hline Silver ion; Citric acid & $\begin{array}{l}\text { Silver: } 0.003 \% \\
\text { Citric acid: } 4.846 \%\end{array}$ & 1 \\
\hline $\begin{array}{l}\text { Sodium hypochlorite; } \\
\text { Sodium carbonate }\end{array}$ & $\begin{array}{l}4.0 \% \\
1.0 \%\end{array}$ & 0.5 \\
\hline
\end{tabular}


was no evidence that the viral load is sufficient to cause infection in humans. When it comes to SARS-CoV-2 infection in animals, there have been few reports and it seems that it could vary in the specimens. Shi and colleagues [128] infected ferrets, cats, and dogs with SARS-CoV- 2 through intranasal viral inoculation. The virus replicated effectively, especially in cats and ferrets. They also replicated the virus in dogs, but they appeared to be less responsive overall to the infection, and pigs and poultry were not susceptible to the infection. However, since there are doubts if the pets could transmit the virus to people and the apparent susceptivity of some animals to SARSCoV-2 infection, the CDC recommends that pets should be kept away from other animals, people outside of the home, and people with confirmed or suspected COVID-19 should avoid contacting with their pets, for the duration of their selfisolation period [129].

\section{Prevention $^{*}$}

Preventing the spread of COVID-19 includes considering horizontal isolation or vertical isolation. The vertical isolation could be done when the rate of infection is controlled and the health public system can support the amount of patients. Horizontal isolation is necessary when the rate of infection is in ascension, in order to flatten the curve. For preventing viral circulation as well as to protect ourselves, it is necessary to adopt social conducts such as those discriminated by WHO and CDC:

a. Isolation of the affected person (selfquarantine);

b. Self-quarantine if you come from an affected place (hospitals) or country;

c. Washing your hands frequently and carefully;

d. Avoid touching your face including mouth, nose, and eyes;

e. Cover your mouth and nose when coughing and sneezing;

*Please check our article "Clinical Trials for COVID-19 - An Urgent Response" in this issue (pages 98-105). f. Travel restrictions from and to the affected countries;

g. Maintaining high-level hygienic condition inhome and surroundings;

h. Use self-protection (adequate mask, protection glasses, alcohol 70\%);

i. If you need to go outside, use the self-protection item (" $\mathrm{h}$ ");

j. Avoid social gathering;

k. Avoid closed places;

1. Maintaining good nutrition;

$\mathrm{m}$. Take social distancing seriously by keeping a distance of 1.5 meters from another person (using self-protection - item "h").

Vaccine development and medicines take time. Henceforth, it is extremely important to follow guidance on social separation, frequent hand washing, and disinfecting home and workplaces [18, 130, 131].

\section{Conclusion}

SARS-CoV-2 is a global threat without effective drugs or vaccines available, and it is spreading fast, affecting worldwide populations, and especially poor people. We described the epidemiology of the disease, the issue of the transmission, and the risk to get ill - especially for old people and those with comorbidities -, the R0 number and CFR, and the prevention policies. Despite the current mortality rate being low, there is evidence that it could be high if the infected person does not have access to medical care. If a large number of people get sick, and we do not manage to flatten the curve with social isolation politics, it will result in the collapse of the health care system, and then the mortality rate will increase fastly. While there is no drug to block the virus and a vaccine does not exist, following social distance is crucial. Meanwhile, the intermediate host and the mechanism of the cross-species spread of the virus should be further investigated, and legislation should be employed to restrict the sale of wild animals, the potential intermediate host(s) of many viruses, to prevent future outbreaks. 


\section{References}

1. Ciotti M, Angeletti S, Minieri M, et al. COVID-19 Outbreak: An Overview. Chemotherapy Published online: April 7, 2020. Doi: $10.1159 / 000507423$

2. Lu H, Stratton CW, Tang Y-W. Outbreak of pneumonia of unknown etiology in Wuhan, China: the mystery and the miracle. J Med Virol 2020;92(4):401-402.

3. Chen, N, Zhou M, Dong X. Epidemiological and clinical characteristics of 99 cases of 2019 novel coronavirus pneumonia in Wuhan, China: a descriptive study. Lancet 395 2020;(10223):507-513

4. Nijuan X, et al. Use of National Pneumonia Surveillance to describe influenza a (H7N9) virus epidemiology, China, 2004-2013. Emerg Infect Dis J 2013;19(11):1784.

5. World Health Organization. Clinical management of severe acute respiratory infection when novel coronavirus (nCoV) infection is suspected: interim guidance. 2020;28.

6. Sohrabi C, et al. World Health Organization declares global emergency: a review of the 2019 novel coronavirus (COVID-19). Int J Surg 2020;76:71-76.

7. Mohamed T, El-Aziza A, Stockanda JD. Severe acute respiratory syndrome coronavirus 2 (SARS-CoV-2) and coronavirus disease-2019 (COVID-19): The epidemic and the challenges. Recent progress and challenges in drug development against COVID-19 coronavirus (SARSCoV-2) - an update on the status. Genetics and Evolution 2020;83:104327.

8. Weiss SR, Navas-Martin S. Coronavirus pathogenesis and the emerging pathogen severe acute respiratory syndrome coronavirus. Microbiol Mol Biol Rev 2005;69(4):635-664.

9. Zumla A, et al. Coronaviruses - drug discovery and therapeutic options. Nat Rev Drug Discov 206;15(5);327-347.

10. $\mathrm{Su} \mathrm{S}$, et al. Epidemiology, genetic recombination, and pathogenesis of coronaviruses. Trends Microbiol. 2016;24(6):490-502.

11. Almeida JD, Tyrrell DA. The morphology of three previously uncharacterized human respiratory viruses that grow in organ culture. J Gen Virol 1967 Apr;1(2):175-8.

12. Kapikian AZ, James HD Jr, Kelly SJ, Dees JH, Turner HC, McIntosh $\mathrm{K}$, et al. Isolation from man of "avian infectious bronchitis viruslike" viruses (coronaviruses) similar to $229 \mathrm{E}$ virus, with some epidemiological observations. J Infect Dis 1969 Mar;119(3):282-90.

13. Peiris JS, Guan Y, Yuen KY. Severe acute respiratory syndrome. Nat Med 2004;Dec 10(12 Suppl):S88-97.

14. van der Hoek L, Pyrc K, Jebbink MF, Vermeulen- Oost W, Berkhout RJ, Wolthers KC, et al. Identification of a new human coronavirus. Nat Med 2004 Apr;10(4):368-73.

15. Woo PC, Lau SK, Chu CM, Chan KH, Tsoi HW, Huang Y, et al. Characterization and complete genome sequence of a novel coronavirus, coronavirus HKU1, from patients with pneumonia. J Virol 2005 Jan;79(2):884-95.

16. Zaki AM, van Boheemen S, Bestebroer TM, Osterhaus $\mathrm{AD}$, Fouchier RA. Isolation of a novel coronavirus from a man with pneumonia in Saudi Arabia. N Engl J Med 2012 Nov;367(19):1814-20.

17. Zhang T, Wu Q, Zhang Z. Probable pangolin origin of SARSCoV-2 associated with the COVID-19 outbreak. Curr Biol 2020;30:1346-1351.
18. Pradhan D, Biswasroy P, Kumar P, et al.. A Review of Current Interventions for COVID-19 Prevention. Archives of Medical Research - April 27, 2020 (ARCMED_2020_549). https:// doi.org/10.1016/j.arcmed.2020.04.020.

19. Zhou P, Yang X-L, Wang X-G, et al. Discovery of a novel coronavirus associated with the recent pneumonia outbreak in 2 humans and its potential bat origin. BioRxiv 2020a.

20. Liu L, et al. Epithelial cells lining salivary gland ducts are early target cells of severe acute respiratory syndrome coronavirus infection in the upper respiratory tracts of rhesus macaques. J Virol 2011;85(8):4025-4030.

21. Adnan SM, et al. COVID-19 infection: origin, transmission, and characteristics of human coronaviruses. J. Adv. Res. 2020;24:91-98

22. Li Q, et al. Early transmission dynamics in Wuhan, China, of novel coronavirus - infected pneumonia. N Engl J Med 2020A;382(13):1199-1207.

23. McMichael TM, Clark S, Pogosjans S, et al. COVID-19 in a Long-Term Care Facility - King County, Washington. MMWR Morb Mortal Wkly Rep 2020;69:339.

24. Mosites E, Parker EM, Clarke KEN, et al. Assessment of SARS-CoV-2 Infection Prevalence in Homeless Shelters - Four U.S. Cities. MMWR Morb Mortal Wkly Rep 2020;69:521.

25. Baggett TP, Keyes H, Sporn N, Gaeta JM. Prevalence of SARS-CoV-2 Infection in Residents of a Large Homeless Shelter in Boston. JAMA 2020.

26 John Hopkins Coronavirus Research Center 2020. https:// coronavirus.jhu.edu/map.html.

27. World Health Organization (WHO) Coronavirus Disease Dashboard https://covid19.who.int/.

28. Worldmeters. https://www.worldometers.info/coronavirus/?.

29. Healthmap Coronavirus (https://www.healthmap.org/ COVID-19/.

30. Uptodate Coronavirus (https://covid19map.uptodate.com/.

31. Health Data for Coronavirus [https://covid19.healthdata.org/.

32. Centers for Disease Control and Prevention (CDC) https:// www.cdc.gov/coronavirus/2019-ncov/global-COVID-19/ world-map.html.

33. Our World in Data-COVID-19. https://ourworldindata.org/.

34. Bulut C, Kato Y. Epidemiology of COVID-19. Turk J Med Sci 2020;50:563-570. Doi:10.3906/sag-2004-172.

35. van Doremalen N, Bushmaker T, Morris DH, et al. Aerosol and surface stability of SARS-CoV-2 as compared with SARS-CoV-1. N Engl J Med 2020;382:1564-1567.

36. Zou L, Ruan F, Huang M, et al. SARS-CoV-2 viral load in upper respiratory specimens of infected patients. N Engl J Med 2020;382:1177-1179.

37. Li R, Pei S, Chen B, et al. Substantial undocumented infection facilitates the rapid dissemination of novel coronavirus (SARS-CoV2). Science. Doi: 10.1126/science.abb3221.

38. de Wit E., van Doremalen N, Falzarano D, Munster VJ. SARS and MERS: recent insights into emerging coronaviruses. Nat Rev Microbiol 2016;14:523-534.

39. Zhou P, et al. A pneumonia outbreak associated with a new coronavirus of probable bat origin. Nature 2020. https://doi. org/10.1038/s41586-020-2012-7.

40. Zheng J. SARS-CoV-2: an Emerging Coronavirus that Causes a Global Threat. International Journal of Biological Sciences 2020;16(10):1678-1685. Doi: 10.7150/ijbs.45053. 
41. McIntosh K. Coronavirus disease 2019 (COVID-19): Epidemiology, virology, and prevention. Wolters Kluwer 2020. www.uptodate.com.

42. Peng X, Xu X, Li Y, et al. Transmission routes of 2019-nCoV and controls in dental practice International Journal of Oral Science. www.nature.com/ijosInternational Journal of Oral Science 2020;12:9, https://doi.org/10.1038/s41368-0200075-9.

43. Lu C-W, Liu X-F, Jia Z-F. 2019-nCoV transmission through the ocular surface must not be ignored. The Lancet https:// doi.org/10.1016/S0140-6736(20)30313-5.

44. World Health Organization. Modes of transmission of virus causing COVID-19: implications for IPC precaution recommendations [online] (2020). Website https://www. who.int/news-room/commentaries/detail/modes-oftransmission-of-virus-causing-COVID-19-implications-foripc-precaution-recommendations.

45. Chen W, Lan Y, Yuan X, et al. Detectable 2019-nCoV viral RNA in blood is a strong indicator for the further clinical severity. Emerg Microbes Infect 2020;9:469.

46. Wang W, Xu Y, Gao R, et al. Detection of SARS-CoV-2 in Different Types of Clinical Specimens. JAMA 2020.

47. Colavita F, Lapa D, Carletti F, et al. SARS-CoV-2 Isolation from ocular secretions of a patient with COVID-19 in Italy with prolonged viral RNA detection. Ann Intern Med 2020.

48. Cheung KS, Hung IF, Chan PP, et al. Gastrointestinal manifestations of SARS-CoV-2 infection and viral load in fecal samples from the Hong Kong Cohort and systematic review and meta-analysis. Gastroenterology 2020.

49. Zheng S, Fan J, Yu F, et al. Viral load dynamics and disease severity in patients infected with SARS-CoV-2 in Zhejiang province, China, January-March 2020: retrospective cohort study. BMJ 2020;369:m1443.

50. Yu F, Yan L, Wang N, et al. Quantitative detection and viral load analysis of SARS-CoV-2 in infected patients. Clin Infect Dis 2020.

51. Huang C, et al. Clinical features of patients infected with 2019 novel coronavirus in Wuhan, China. Lancet 2020;395:497506.

52. To KK-W, et al. Consistent detection of 2019 novel coronavirus in saliva. Clin Infect Diseases 2020. https://doi. org/10.1093/cid/ciaa149.

53. Belser JA, Rota PA, Tumpey TM. Ocular tropism of respiratory viruses. Microbiol Mol Biol Rev 2013;77:144156.

54. Zhang W, Du RH, Li B, Zheng XS, Yang XL, Hu B, et al. Molecular and serological investigation of 2019-nCoV infected patients: implication of multiple shedding routes. Emerg Microbes Infect 2020;9:386-9.

55. Cheng-wei LX-L, Zhi-fang J. 2019-nCoV transmission through the ocular surface must not be ignored. The Lancet 2020;36:30313-5.

56. Wax RS, Christian MD. Practical recommendations for critical care and anesthesiology teams caring for novel coronavirus (2019-nCoV) patients. Canadian Journal of Anesthesia/Journal canadien d'anesthésie 2020. https://doi. org/10.1007/ s12630-020-01591-x.

57. Peng X, Xu X, Li Y, Cheng L, Zhou X, Ren B. Transmission routes of 2019-nCoV and controls in dental practice. Int J Oral Sci 2020;12(1):9.
58. Rothe C, et al. Transmission of 2019-nCoV infection from an asymptomatic contact in germany. N Engl J Med 2020. https://doi.org/10.1056/NEJMc2001468.

59. Kupferschmidt K. Study claiming new coronavirus can be transmitted by people without symptoms was flawed. Science 2020. https://www.sciencemag.org/news/2020/02/paper-nonsymptomatic-patie nt-transmitting-coronavirus-wrong.

60. Bai Y, Yao L, Wei T, Tian F, Jin DY, Chen L, et al. Presumed Asymptomatic Carrier Transmission of COVID-19. JAMA 2020.

61. Hoehl S, Berger A, Kortenbusch M, Cinatl J, Bojkova D, Rabenau $\mathrm{H}$, et al. Evidence of SARS-CoV-2 Infection in Returning Travelers from Wuhan, China. N Engl J Med 2020.

62. Xu K, Chen Y, Yuan J, et al. Factors associated with prolonged viral RNA shedding in patients with COVID-19. Clin Infect Dis 2020.

63. Ong SWX, Tan YK, Chia PY, et al. Air, surface environmental, and personal protective equipment contamination by severe acute respiratory syndrome coronavirus 2 (SARS-CoV-2) from a symptomatic patient. JAMA 2020

64. Guo ZD, Wang ZY, Zhang SF, et al. Aerosol and surface distribution of severe acute respiratory syndrome coronavirus 2 in hospital wards, Wuhan, China, 2020. Emerg Infect Dis 2020;26.

65. Liu Y, Ning Z, Chen Y, et al. Aerodynamic analysis of SARSCoV-2 in two Wuhan hospitals. Nature 2020.

66. Bahl P, Doolan C, de Silva C, et al. Airborne or droplet precautions for health workers treating COVID-19? J Infect Dis 2020.

67. Amirian S. Potential fecal transmission of SARS-CoV-2: Current evidence and implications for public health. International Journal of Infectious Diseases 2020;95:363-370.

68. Gu J, Han B, Wang J. COVID-19: gastrointestinal manifestations and potential fecal-oral transmission. Gastroenterology 2020.

69. Wang XW, Li J, Guo T, Zhen B, Kong Q, Yi B, et al. Concentration and detection of SARS coronavirus in fecal samples. JAMA 2020.

70. Xiao F. Hospital and the $309^{\text {th }}$ Hospital of the chinese people's liberation army. Water Sci Technol 2005;52(8):213-21.

71. Xiao F, Tang M, Zheng X, Liu Y, Li X, Shan H. Evidence for gastrointestinal infection of SARS-CoV-2. Gastroenterology 2020

72. Yeo C, Kaushal S, Yeo D. Enteric involvement of coronaviruses: is faecal-oral transmission of SARS-CoV-2 possible?. Lancet Gastroenterol Hepatol 2020;5(4):335.

73. He Y, Wang Z, Li F, Shi Y. Public health might be endangered by possible prolonged discharge of SARS-CoV-2 in stool. J Infect 2020

74. Zhang H, Kang Z, Gong H, Xu D, Wang J, Li Z, et al. The digestive system is a potential route of 2019-nCov infection: a bioinformatics analysis based on single-cell transcriptomes. 2020

75. Guan WJ, Ni ZY, Hu Y, Liang WH, Ou CQ, et al. Clinical characteristics of coronavirus disease 2019 in China. The New England Journal of Medicine 2020;NEJMoa2002032. Doi: 10.1056/NEJMoa2002032.

76. Wölfel R, Corman VM, Guggemos W, Seilmaier M, Zange S. Virological assessment of hospitalized patients with COVID-2019. Nature 2020; April 1. Doi: 10.1038/s41586020-2196-x 25. 
77. Wu Y, Gou C, Tang L, Hong Z, Zhou J, et al. Prolonged presence of SARS-CoV-2 viral RNA in faecal samples. Lancet Gastroenterology and Hepatolology 2020;(5):434435. Doi: 10.1016/S2468-1253(20)30083-2.

78. de Graaf M, Beck R, Caccio SM, Duim B, Fraaij P, Le Guyader FS, et al. Sustained fecal-oral human-to-human transmission following a zoonotic event. Curr Opin Virol 2017;22:1-6.

79. World Health Organization. Sanitaton fact sheet. 2019 Available from: https://www. who.int/news-room/fact-sheets/ detail/sanitation.

80. Centers for Disease Control \& Prevention. Water transmission and COVID-19. 2020 Available from: https://www.cdc.gov/ coronavirus/2019-ncov/php/water.html.

81. U.S. Department of Homeland Security. Guidance on the essential critical infrastructure workforce. 2020 Available from: https://www.cisa.gov/publica- tion/guidance-essentialcritical-infrastructure-workforce.

82. Weiss P, Murdoch DR. Clinical course and mortality risk of severe COVID-19. Lancet 2020.

83. Schwartz DA. An analysis of 38 pregnant women with COVID-19, their newborn infants, and maternal-fetal transmission of SARS-CoV-2: maternal coronavirus infections and pregnancy outcomes. Archives of Pathology and Laboratory Medicine 2020;March 17. Doi: 10.5858/ arpa.2020-0901-AS.

84. Dashraath P, Jeslyn WJL, Karen LMX, Min LL, Sarah L, et al. Coronavirus disease 2019 (COVID-19) pandemic and pregnancy. American Journal of Obstetrics and Gynecology 2020; March 23. Doi: 10.1016/j.ajog.2020.03.021.

85. Chen H, Guo J, Wang C, Luo F, Yu X, Zhang W, et al. Clinical characteristics and intrauterine vertical transmission potential of COVID-19 infection in nine pregnant women: a retrospective review of medical records. Lancet 2020a;395 (10226):809-1529.

86. Li Y, Zhao R, Zheng S, Chen X, Wang J, Sheng X, et al. Lack of vertical transmission of severe acute respiratory syndrome coronavirus 2, China. Emerg Infect Dis 2020;26(6).

87. Qian G, Yang N, Ma AHY, et al. A COVID-19 Transmission within a family cluster by presymptomatic infectors in China. Clinical Infectious Diseases 2020 March 23; ciaa316. Doi: 10.1093/cid/ciaa316.

88. Wei WE, Li Z, Chiew CJ, Yong SE, Toh MP, et al. Presymptomatic transmission of SARS-CoV-2-Singapore, January 23-March 16, 2020. MMWR Morbidity Mortality Weekly Report 202069 (14): 411-415. Doi: 10.15585/mmwr.mm6914e1.

89. Ardura M, Hartley D, Dando C, Transplant-Associated Learning Network Team (TALNT). COVID-19: An Overview. Epidemiology and transmissibility Biology of Blood and Marrow Transplantation 2020.

90. Dietz K. The estimation of the basic reproduction number for infectious diseases. Stat Methods Med Res 1993;2:23-41.

91. Wu JT, Leung K, Leung GM. Nowcasting and forecasting the potential domestic and international spread of the 2019-nCoV outbreak originating in Wuhan, China: a modelling study. Lancet 2020.

92. Zhao S, Lin Q, Ran J, Musa SS, Yang G, Wang W, et al. Preliminary estimation of the basic reproduction number of novel coronavirus (2019-nCoV) in China, from 2019 to 2020: a data-driven analysis in the early phase of the outbreak. Int $\mathrm{J}$ Infect Dis 2020;92:214-17. Doi: 10.1016/j.ijid.2020.01.050.
93. Sanche S, Lin YT, Xu C, Romero-Severson E, Hengartner $\mathrm{N}, \mathrm{Ke} \mathrm{R}$. High contagiousness and rapid spread of severe acute respiratory syndrome Coronavirus 2. Emerg Infect Dis J 2020:26:1-19.

94. Sanche S, Lin YT, Xu C, Romero-Severson E, Hengartner $\mathrm{N}$, Ke R. The Novel Coronavirus, 2019-nCoV, is Highly Contagious and More Infectious Than Initially Estimated. medRxiv 2020. Doi: https://Doi.org/10.1101/2020.02.07.200 21154 .

95. Liu Y, GayleAA, Wilder-Smith A, Rocklöv J. The reproductive number of COVID-19 is higher compared to SARS coronavirus. Journal of Travel Medicine 2020;27(2):taaa021. /doi: 10.1093/jtm/taaa021.

96. Bauch CT, Lloyd-Smith JO, Coffee MP, Galvani AP. Dynamically modeling SARS and other newly emerging respiratory illnesses: past, present, and future. Epidemiology 2005;16:791-801.

97. Yang Y, Liu MJ, Wang YX, Zhang AR, Jalali Neda, Dean Natalie, et al. Epidemiological and clinical features of the 2019 novel coronavirus outbreak in China. MedRxiv 2020. Doi:http://dx.doi.org/10.1101/2020.02.10.20021675.

98. Backer JA, Klinkenberg D, Wallinga J. Incubation period of 2019 novel coronavirus (2019-nCoV) infections among travellers from Wuhan, China, 20-28 January 2020. Euro Surveill 2020;25, Doi:http://dx.doi.org/10.2807/1560- 7917. ES.2020.25.5.2000062.

99. Lesser J, Reich NG, Brookmeyer R, Perl TM, Nelson KE, Cummings DA. Incubation periods of acute respiratory viral infections: a systematic review. Lancet Infect Dis 2009;9:291-300.Doi:http://dx.doi.org/10.1016/S14733099(09)70069- 6.

100. Park JE, Jung S, Kim A, Park JE. MERS transmission and risk factors: a systematic review. BMC Public Health 2018;18:574.Doi:http://dx.doi.org/10.1186/s12889-0185484-8.

101. Lipsitch M, Cohen T, Cooper B, Robins JM, Ma S, James $\mathrm{L}$, et al. Transmission dynamics and control of severe acute respiratory syndrome. Science 2003;300:1966-70. Doi:http:// dx.doi.org/10.1126/science.1086616.

102. Lauer SA, Grantz KH, Bi Q, Jones FK, Zheng Q, et al. The incubation period of coronavirus disease 2019 (COVID-19) from publicly reported confirmed cases: estimation and application. Annals of Internal Medicine 2020;March 10. Doi: 10.7326/M20-0504.

103. Xie M, Chena Q. Insight into 2019 novel coronavirus - An updated interim review and lessons from SARS-CoV and MERS-CoV International Journal of Infectious Diseases 2020;94:119-124.

104. Yuan J, Li M, Lv G, Lu ZK. Monitoring Transmissibility and Mortality of COVID-19 in Europe. International Journal of Infectious Diseases 2020; Mar 28. Doi: 10.1016/j. ijid.2020.03.050.

105. Saxena SK. Coronavirus Disease 2019 (COVID-19). Epidemiology, pathogenesis, diagnosis, and therapeutics. Springer, 2020.

106. To KK, Tsang OT, Leung WS, et al. Temporal profiles of viral load in posterior oropharyngeal saliva samples and serum antibody responses during infection by SARSCoV-2: an observational cohort study. Lancet Infect Dis 2020;20:565. 
107. COVID-19 Investigation Team. Clinical and virologic characteristics of the first 12 patients with coronavirus disease 2019 (COVID-19) in the United States. Nat Med 2020.

108. Rothe C, Schunk M, Sothmann P, et al. Transmission of 2019$\mathrm{nCoV}$ infection from an asymptomatic contact in Germany. $\mathrm{N}$ Engl J Med 2020;382:970.

109. Yu P, Zhu J, Zhang Z, et al. A familial cluster of infection associated with the 2019 novel coronavirus indicating potential person-to-person transmission during the incubation period. J Infect Dis 2020 .

110. Hu Z, Song $\mathrm{C}, \mathrm{Xu} \mathrm{C}$, et al. Clinical characteristics of 24 asymptomatic infections with COVID-19 screened among close contacts in Nanjing, China. Sci China Life Sci 2020;63:706-42.

111. Arons MM, Hatfield KM, Reddy SC, et al. Presymptomatic SARS-CoV-2 infections and transmission in a skilled nursing facility. N Engl J Med 2020.

112. Liu Y, Yan LM, Wan L, et al. Viral dynamics in mild and severe cases of COVID-19. Lancet Infect Dis 2020.

113. Zhou F, Yu T, Du R, et al. Clinical course and risk factors for mortality of adult inpatients with COVID-19 in Wuhan, China: a retrospective cohort study. Lancet 2020;395:1054.

114. Xiao AT, Tong YX, Zhang S. Profile of RT-PCR for SARSCoV-2: a preliminary study from 56 COVID-19 patients. Clin Infect Dis 2020.

115. Centers for Disease Control and Prevention. Symptom-based strategy to discontinue isolation for persons with COVID-19: Decision Mem. https:/www.cdc.gov/coronavirus/2019-ncov/ community/strategy-discontinue-isolation.html.

116. United States Environmental Protection Agency. List: Disinfectants for use against SARS-CoV-2. https://www.epa. gov/pesticide-registration/list-n-disinfectants-use-againstsars-cov-2.

117. Wilson N, Kvalsvig A, Barnard LT, Baker MG. Case-fatality risk estimates for COVID-19 calculated by using a lag time for fatality. Emerg Infect Dis 2020:26.

118. Omer SB, Malani P, Del Rio C. The COVID-19 pandemic in the US: a clinical update. JAMA. Doi: 10.1001/ jama.2020.5788.75, 101.

119. Fauci AS, Lane HC, Redfield RR. COVID-19 - navigating the uncharted. N Engl J Med 2020;382:1268-1269.

120. Ruan Q, Yang K, Wang W, Jiang L, Song J. Clinical predictors of mortality due to COVID-19 based on an analysis of data of 150 patients from Wuhan, China. Intensive Care Med. Doi: 10.1007/s00134-020-05991.
121. Wang D, Hu B, Hu C, et al. Clinical characteristics of 138 hospitalized patients with 2019 novel coronavirus-infected pneumonia in Wuhan, China. JAMA. Doi: https://doi. org/10.1001/jama.2020.1585.

122. WHO. Summary of probable SARS cases with onset of illness from 1 November 2002 to 31 July 2003. 2020. https:// www.who.int/csr/sars/country/table2004_04_21/en/.

123. Yang J, Zheng Y, Gou X, Pu K, Chen Z, et al. Prevalence of comorbidities in the novel Wuhan coronavirus (COVID-19) infection: a systematic review and meta-analysis. International Journal of Infectious Diseases. 2020; March 12. Doi: 10.1016/j.ijid.2020.03.017.

124. Emami A, Javanmardi F, Pirbonyeh N, Akbari A. Prevalence of underlying diseases in hospitalized patients with COVID-19: a systematic review and metaanalysis. Archieves of Academic Emergency Medicine 2020;8(1):e35.

125. Istituto Superiore di Sanità (2020). Characteristics of COVID-19 patients dying in Italy Report based on available data on April 2nd, 2020 [online]. Website https:// www.epicentro.iss.it/en/coronavirus/bollettino/ReportCOVID-2019_2_april_2020.pdf.

126. Lippi G, Wong J, Henry BM. Hypertension and its severity or mortality in coronavirus disease 2019 (COVID-19): a pooled analysis. Polish Archives of Internal Medicine 2020; March 31, [Epub ahead of print]. Doi: 10.20452/pamw.15272.

127. Yang S, et al. Early estimation of the case fatality rate of COVID-19 in mainland China: a data-driven analysis. Ann Transl Med 2020b;8(4):128.

128. Shi J, Wen Z, Zhong G, et al. Susceptibility of ferrets, cats, dogs, and other domesticated animals to SARS-coronavirus 2. Science 2020.

129. World Organization for Animal Health. Questions and Answers on the 2019 Coronavirus Disease (COVID-19), section on Surveillance and events in animals. https://www. oie.int/en/scientific-expertise/specific-information-andrecommendations/questions-and-answers-on-2019no.

130. Jin $\mathrm{Y}-\mathrm{H}$, et al. A rapid advice guideline for the diagnosis and treatment of 2019 novel coronavirus (2019-nCoV) infected pneumonia (standard version). Military Medical Research 2020;7(1):4

131. Wang P, et al. The SARS-CoV-2 outbreak: diagnosis, infection prevention, and public perception. Clin Chem 2020c. https:// doi.org/10.1093/clinchem/hvaa080. 